\title{
Virus genomes and virus-host interactions in aquaculture animals
}

\author{
ZHANG QiYa* \& GUI Jian-Fang \\ State Key Laboratory of Freshwater Ecology and Biotechnology, Institute of Hydrobiology, Chinese Academy of Sciences, University of the \\ Chinese Academy of Sciences, Wuhan 430072, China
}

Received September 15, 2014; accepted October 29, 2014; published online January 14, 2015

\begin{abstract}
Over the last 30 years, aquaculture has become the fastest growing form of agriculture production in the world, but its development has been hampered by a diverse range of pathogenic viruses. During the last decade, a large number of viruses from aquatic animals have been identified, and more than 100 viral genomes have been sequenced and genetically characterized. These advances are leading to better understanding about antiviral mechanisms and the types of interaction occurring between aquatic viruses and their hosts. Here, based on our research experience of more than 20 years, we review the wealth of genetic and genomic information from studies on a diverse range of aquatic viruses, including iridoviruses, herpesviruses, reoviruses, and rhabdoviruses, and outline some major advances in our understanding of virus-host interactions in animals used in aquaculture.
\end{abstract}

aquaculture, viral genome, antiviral defense, iridoviruses, reoviruses, rhabdoviruses, herpesviruses, host-virus interactions

Citation: $\quad$ Zhang QY, Gui JF. Virus genomes and virus-host interactions in aquaculture animals. Sci China Life Sci, 2015, 58: 156-169 doi: $10.1007 / \mathrm{s} 11427-015-4802-y$

Aquaculture has become the fastest and most efficient agricultural production industry in the world over the last three decades, and China is believed to be a major contributor to it [1-3]. According to official figures, the production of aquatic products has reached 61.72 million tons, with the 45.6 million tons from aquaculture accounting for $73.9 \%$ of the total produced [4]. Over the last 20 years, China's aquaculture output has accounted for about $2 / 3$ of the total global aquaculture production [5]. However, viral diseases, which have been frequently reported in aquaculture animals, have hampered aquaculture development [6-8]. Concurrently, a natural decline in populations of aquatic vertebrates, especially the global decline or extinction events seen with some frogs and amphibians, have been reported by ecologists; hence, the question "why are all the frogs

*Corresponding author (email: zhangqy@ihb.ac.cn) "croaking'?" has been asked [9-11]. To help resolve these problems, researchers have looked for and identified a large number of diverse pathogenic viruses in aquaculture and natural aquatic animals including iridoviruses, herpesviruses, reoviruses and rhabdoviruses; these pathogenic iridoviruses have been found to be the cause of epizootic diseases in aquaculture animals and the global decline of amphibian populations [12-15]. In the last 10 years especially, more than 100 viral genomes have been genetically characterized via the rapid advances in genome sequencing technologies [16-19]. These advances have enabled great progress to be made in understanding the mechanisms underlying interactions between viruses and their aquatic host animals [19]. Here, we review recent progress in the genomic and genetic characterization of some important pathogenic viruses, such as iridoviruses, herpesviruses, reoviruses, and rhabdoviruses, and virus-host interactions in aquaculture animals. 


\section{Iridoviruses and their genomes}

Iridoviruses (family Iridoviridae) comprise the following five genera: Ranavirus, Lymphocystivirus, Megalocytivirus, Iridovirus and Chloriridovirus. The genomes of this family of viruses generally contain a single molecule of double-stranded DNA [19,20]. Ranavirus, Lymphocystivirus and Megalocytivirus infect more than 140 species of aquatic vertebrates including fish, amphibians and reptiles, and cause high mortality in aquaculture and problems with wildlife conservation [19-21]. For example, lymphocystis disease virus (LCDV), has been identified as the causative agent of lymphocystis disease in more than 100 different seawater and freshwater fish species [22,23]. In particular, diverse ranaviruses (genus Ranavirus) have been reported to infect about 70 amphibian species from at least 14 families, more than 100 fish species and dozens of reptiles; hence, some experts believe that ranaviruses infect not only frogs but also numerous different aquatic vertebrates, and are, therefore, promiscuous pathogens of cold-blooded vertebrates [24-33].

In total, 22 genomes from Ranavirus, Lymphocystivirus and Megalocytivirus have been completely sequenced; the smallest $(105 \mathrm{~kb})$ is that of the tiger frog virus (TFV), while the largest $(186 \mathrm{~kb})$ belongs to the Chinese strain of LCDV (LCDV-C) (Table 1).

Table 1 Known iridoviruses of aquatic animals and their genomes

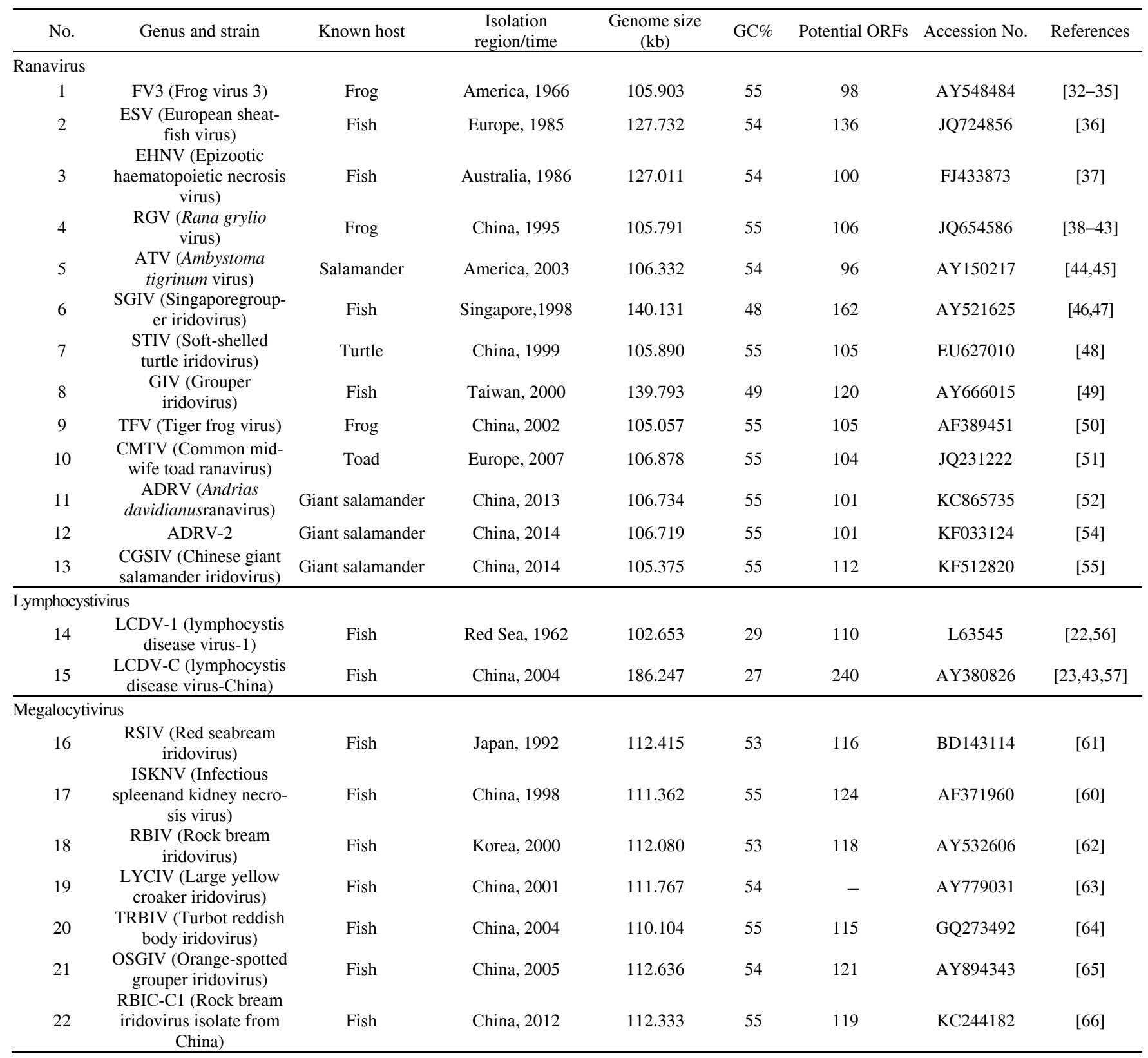




\subsection{Ranaviruses and their genomes}

The following 13 ranavirus genomes have been completely sequenced: (i) Frog virus 3 is a species of the genus $R a$ navirus. Frog virus 3 infection results in considerable morbidity and mortality in a wide range of wild and cultivated amphibian species [32-35]. (ii) European sheatfish virus is a fish ranavirus isolated from moribund sheatfish (Silurus glanis) fry [36]. (iii) Epizootic hematopoietic necrosis virus is a fish ranavirus that causes serious hematopoietic necrosis in redfin perch and rainbow trout, resulting in serious economic losses in aquaculture and severe decline in wild populations of these fish [37]. (iv) Rana grylio virus (RGV). $\mathrm{RGV}$, a ranavirus isolated from China, causes systemic hemorrhagic disease with a high mortality rate in frogs. It is also a model system for molecular characterization of ranaviruses [38-43]. (v) Ambystoma tigrinum virus is a lethal ranavirus originally isolated from Sonora tiger salamanders in southern Arizona, USA [44,45]. (vi) Singapore grouper iridovirus is a fish ranavirus isolated from a diseased grouper in Singapore [46,47]. (vii) Soft-shelled turtle iridovirus is a reptile ranavirus that causes viral disease in cultured soft-shelled turtles [48]. (viii) Grouper iridovirus is a fish ranavirus isolated from the spleen tissues of a diseased yellow grouper [49]. (ix) TFV is a frog ranavirus isolated from diseased tiger frogs [50]. (x) Common midwife toad ranavirus is a toad ranavirus responsible for an outbreak of a systemic hemorrhagic disease that caused high mortality in toads from northern Spain [51]. (xi) Andrias davidianus ranavirus (ADRV), the first sequenced ranavirus, is associated with high mortality in Chinese giant salamanders [52]. This ranavirus causes high mortality in wild and farmed Chinese giant salamanders [52,53]. (xii) ADRV-2, another ranavirus strain isolated from Chinese giant salamanders after ADRV, shares a high level genome identity with ADRV [54]. (xiii) Finally, the Chinese giant salamander iridovirus, which is another ADRV, is the third sequenced ADRV strain [55].

Based on their genome sizes, gene contents and phylogenetic analyses, the sequenced ranaviruses (Table 1) have been divided into two subgroups: the amphibian subgroup and the fish subgroup. The amphibian subgroup includes ADRV, Common midwife toad ranavirus, RGV, Frog virus 3, TFV, and Ambystoma tigrinum virus, while the fish subgroup comprises Epizootic hematopoietic necrosis virus, European sheatfish virus, Grouper iridovirus, and Singapore grouper iridovirus [52]. From extensive analysis of the genome architectures and major genes of this diverse array of ranaviruses (especially ADRV and RGV genomes), we have proposed a hypothetical evolutionary model for ADRV [52]. In this model, ADRV is proposed to emerge (with its current genome) from a common ancestor of the amphibian ranavirus subgroup through changes in its genome architecture and variations in some of its major virulence-related genes (Figure 1). This hypothesis is based on the architec- tural changes observed in current ranavirus genomes; these include segment inversion, fragment insertion and deletion, and several variations in major genes, such as high diversification in two duplicate genes encoding the US22 family-like proteins, truncated domains in the virulence-related gene encoding vIF $2 \alpha$, and the appearance of novel genes with nuclear localization signal and nuclear export signal motifs [52]. Therefore, our current model provides possible routes leading to evolutionary genetic change and crossspecies transmission mechanisms in this diverse range of ranaviruses.

\subsection{LCDV genomes}

LCDVs (genus Lymphocystivirus) cause lymphocystis disease in marine and freshwater fish. The genomes of two LCDVs, LCDV-1 and LCDV-C have been completely sequenced. LCDV-1, which infects plaice and flounder, was isolated from the propagated cell lines of bluegill and centrarchid fish in 1966 [32-35] and had its genome completely sequenced in 1997 [22]. LCDV-C was originally iso-

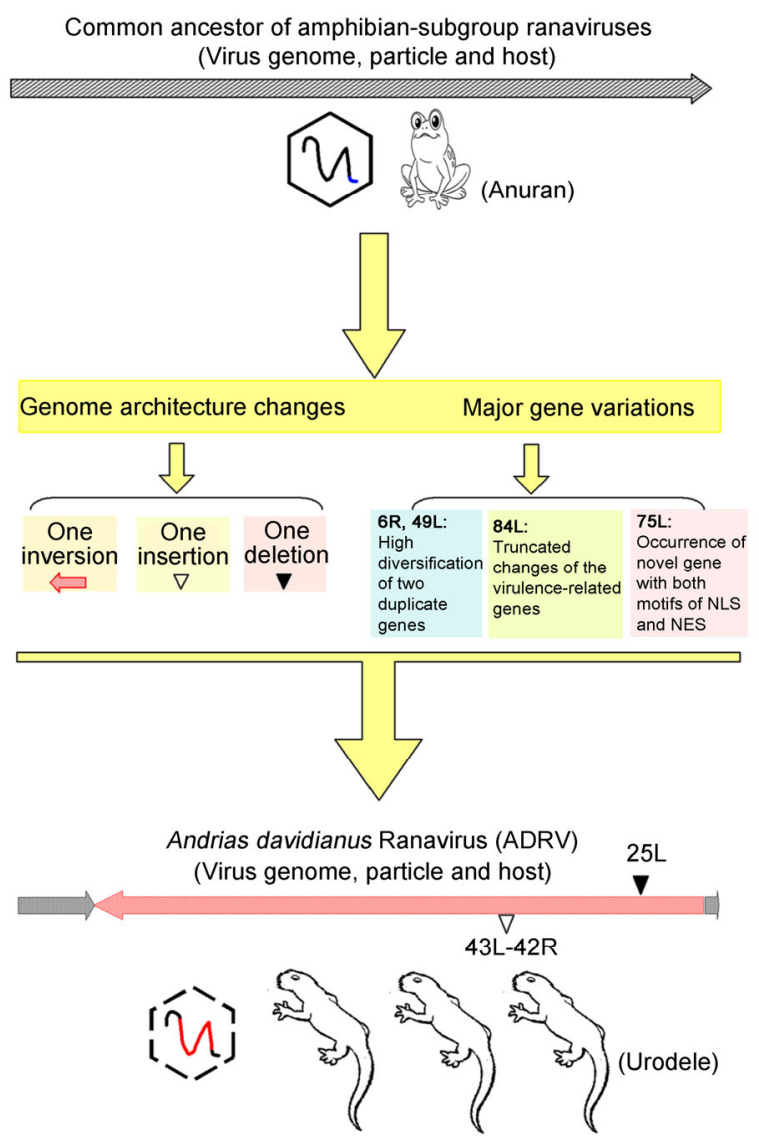

Figure 1 A hypothetical model of ADRV evolutionary emergence from a common ancestor of the amphibian subgroup of ranaviruses. During evolutionary processes, several changes leading to the current genome architecture and major virulence-related gene variations are proposed to have happened. Red hatched arrow: genome segment inversion; black triangles: fragment insertion; blank triangles: fragment deletion; 6R, 49L, 84L, 75L and 25L: different open reading frames (ORFs) in ADRV genome [52]. 
lated from a flounder with lymphocystis disease by Chinese scientists in 2003, and its complete genome sequence was reported in 2004 [23,43,57]. The LCDV-C genome remains the largest among all known vertebrate iridoviruses sequenced thus far (Table 1).

It is worth mentioning that LCDV-C is listed as a typical Iridoviridae strain in the "Virus Taxonomy Ninth Report" by the International Committee on Taxonomy of Viruses [20]. LCDV-C genomic data can be used as a reference resource for identifying other LCDVs and iridoviruses and for performing gene function analyses. This resource will enable virologists to explore the genetic characteristics of these large DNA viruses. In addition, several novel emerging LCDVs, such as LCDV-PF from the paradise fish Macropodus opercularis [58], and GLCDV, which was isolated from cultured grouper [59], have been identified.

\subsection{Megalocytivirus genomes}

To date, seven megalocytiviruses have been subjected to complete genome sequencing: (i) Infectious spleen and kidney necrosis virus-a megalocytivirus causing high mortality in mandarin fish-is characterized by cell hypertrophy in the spleen, kidney, cranial connective tissue and endocardium of this fish [60]. (ii) Red sea bream iridovirus is a piscine iridovirus that causes an acute and highly contagious disease in Red sea bream from Japan and Korea [61]. (iii) Rock bream iridovirus is a megalocytivirus that occurs in cultured rock bream from Korea [62]. (iv) Large yellow croaker iridovirus is a megalocytivirus causing gill paleness, liver congestion, spleen and kidney hypertrophy in cultured large croaker [63]. (v) Turbot reddish body iridovirus is a megalocytivirus that causes serious systemic diseases with high mortality in cultured turbot [64]. (vi) Orange-spotted grouper iridovirus is the causative agent of serious systemic diseases with high mortality in the cultured orange-spotted grouper [65]. (vii) Lastly, rock bream iridovirus isolated from China, is a megalocytivirus that caused a severe disease epidemic in Chinese farmed rock bream [66].

Iridoviruses of the Ranavirus and Lymphocystivirus genera have broadly similar genome sizes and potential gene contents as iridoviruses of the Megalocytivirus genus; their genome sizes range from 110 to $113 \mathrm{~kb}$, while their potential number of genes range from 115 to 124 (Table 1).

\subsection{Important core genes and their functions in iridoviruses}

Gene annotation and comparative genomic analysis have confirmed there are 26 core genes in iridoviruses [67]. Extensive comparisons of these important core genes has provided evidence for cross-species transmission in these iridoviruses, especially for the ranaviruses [68,69]. Moreover, some important genes encoding enzymes, structural proteins and immune-related proteins, such as the RGV $3 \beta$ - hydroxysteroid dehydrogenase gene ( $R G V$ 3 3 -HSD) [70] and the RGV deoxyuridine triphosphatase gene (RGV dUTPase) [71], have been characterized and functionally analyzed. LCDV-C thymidylate synthase (LCDV-C TS) is able to promote cell cycle progression into $\mathrm{S}$ and $\mathrm{G} 2 / \mathrm{M}$ phase. In comparison with control cells, TS-expressed cells have faster growth rates, and induce foci formation and anchorage-independent growth. These findings indicate that LCDV-C TS potentially exhibits the ability to transform cells (tumor formation) [72].

RGV $53 R$ is a core gene in iridoviruses, and encodes a viral envelope protein that plays an important role in virus assembly and infection [73,74]. Recently, we have chosen RGV $53 R$ as a target gene to construct a conditional lethal recombinant RGV (i53R-RGV-lacIO) containing the inducible lac repressor/operator system that can be regulated by IPTG, and have found that the $53 R$ expression level, plaque formation ability and viral titers in i53R-RGV-lacIO are significantly reduced in the absence of IPTG. These results indicate that RGV $53 R$ is not only essential for virus replication and assembly, but also contributes to virus infection and virion formation [75]. RGV 50L contains a nuclear localization signal and helix-extension-helix motif, and is an immediate-early gene. Immuno-fluorescence assays indicate that $50 L$ expression occurs early during infection and persists in RGV-infected cells. RGV 50L exhibits a cytoplasm-nucleus-viromatrix distribution pattern and viromatrix distribution pattern, indicating that it encodes a structural protein, and plays an important role in viral assembly and life cycle [76]. RGV $2 L$ is a core gene encoding an envelope protein. To investigate the role of $2 L$ in viral infections, we constructed a conditional lethal mutant virus containing the lac repressor/operator system and dual fluorescent labeling. Significantly, when $2 L$ expression is repressed, its plaque formation ability and virus titers were strongly reduced. Functional analysis indicates that the $2 L$ protein is essential for iridovirus infection and its study has provided new insights into iridovirus envelope proteins [77].

Besides the controllable recombinant virus technique mentioned above [77], gene knockout methodology has been also used to investigate gene function in iridoviruses [78]. Expression inhibition of a structural protein gene and RNA polymerase gene by morpholino knockdown or gene-specific silencing has been observed to cause a significant reduction in the yield of virus progeny $[79,80]$. Additionally, analysis of gene expression timing and infection pathways have been undertaken in iridovirus using transcriptomics [81]. For example, transcriptional analysis of TFV infection (along with other approaches) has revealed that TFV entry into HepG2 cells occurs via a pH-dependent, atypical, caveola-mediated endocytosis pathway [82]. Also, miRNAs have been recently found to have a significant impact on interactions between iridoviruses and their host aquaculture animals [83]; indeed, some miRNAs may me- 
diate viral evasion [84]

\section{Aquareovirus genomes}

All members of the virus Reoviridae family are nonenveloped, and their genomes are composed of multiple $(10,11$, or 12) segments of linear double-stranded RNAs housed within an icosahedral capsid. This family contains two subfamilies (Spinareovirinae and Sedoreovirinae) and 15 different genera (Aquareovirus, Orthoreovirus, Orbivirus, Rotavirus, Coltivirus, Seadornavirus, Cardoreovirus, Cypovirus, Idnoreovirus, Phytoreovirus, Fijivirus, Oryzavirus, Mycoreovirus, Mimoreovirus, and Dinovernavirus) [20].

Reoviruses that infect aquaculture fish belong to the $A q$ uareovirus genus, and their genomes generally contain 11 segments of linear double-stranded RNA $[85,86]$. At least 15 reovirus genomes have been completely sequenced (Table 2). Of these, 11 reoviruses are different isolates from cultured grass carp obtained in various years and from different regions [85,87-92]; the other four reoviruses were isolated from cultured golden shiner, chum salmon, Atlantic salmon (Piscine reovirus), and turbot (Scophthalmus maximus reovirus), respectively [93-95].

Recently, our laboratory analyzed and compared the complete genome sequences and major core protein sequences of various grass carp reoviruses (GCRV), and this revealed significant genetic diversity among them $[87,90]$. GCRV can be divided into three groups. Most of them cluster into the first major group; these viruses are not cytopathic and contain a fiber-like protein. GCRV members of the second group are cytopathic and possess a fusionassociated small transmembrane (FAST) protein. GCRV 104 , a lone member of the third group, is also cytopathic and has a fiber-like protein. However, the various genotypes are not associated with their regional distributions [90]. Therefore, more studies on the evolutionary and geographical relationships between genomic diversity and reovirus transmission should be performed on grass carp reoviruses.

Scophthalmus maximus reovirus, a novel reovirus isolated from marine fish, contains a FAST protein translated from a non-AUG start site that has been shown to partially contribute to the cytopathic effect caused by infection with this virus [94]. As a new reovirus equally related to members of the Orthoreovirus and Aquareovirus genera, Piscine reovirus, which is linked to heart and skeletal muscle inflammation in farmed Atlantic salmon (Salmo salar L.), has been suggested by whole genome comparisons to be more closely related to orthoreoviruses and, therefore, a new species of the Orthoreovirus genus [96]. Genome comparisons show that Piscine reovirus contains 10 genomic segments

Table 2 Known aquareoviruses and their genomes

\begin{tabular}{|c|c|c|c|c|c|c|c|}
\hline No. & Virus strains & Host & $\begin{array}{l}\text { Isolation } \\
\text { region/time }\end{array}$ & $\begin{array}{l}\text { Genome size } \\
(\mathrm{kb})\end{array}$ & $\begin{array}{l}\text { Segments/ } \\
\text { ORFs }\end{array}$ & Accession No. & References \\
\hline 1 & $\begin{array}{l}\text { GCHV (Grass carp } \\
\text { hemorrhage virus }\end{array}$ & Grass carp & China, 1980 & 21.366 & $11 / 11$ & $\begin{array}{c}\text { AF260511-3 AF251262 F239175 } \\
\text { AF239174 F259053 AF284504 } \\
\text { F236688 F234321 }\end{array}$ & {$[85]$} \\
\hline 2 & $\begin{array}{l}\text { GCRV-873 (Grass carp } \\
\text { reovirus- } 873 \text { ) }\end{array}$ & Grass carp & China, 1983 & 25.000 & $11 / 12$ & $\begin{array}{l}\text { AF260511-3 } \\
\text { AF403390-7 }\end{array}$ & [85] \\
\hline 3 & $\begin{array}{l}\text { AGCRV (American grass } \\
\text { carp reovirus) }\end{array}$ & Grass carp & America, 2001 & 23.576 & $11 / 12$ & EF589098-EF589108 & [91] \\
\hline 4 & $\begin{array}{l}\text { GCRV-HuNan794 (Grass } \\
\text { carp reovirus-HuNan794) }\end{array}$ & Grass carp & China, 2007 & 24.780 & $11 / 11$ & KC238676-KC238686 & {$[92]$} \\
\hline 5 & $\begin{array}{l}\text { GCRV HZ08 (Grass carp } \\
\text { reovirus HZ08) }\end{array}$ & Grass carp & China, 2008 & 24.707 & $11 / 11$ & $\begin{array}{l}\text { GQ896334-7 } \\
\text { GU350742-8 }\end{array}$ & {$[87]$} \\
\hline 6 & $\begin{array}{l}\text { GCRV106 (Grass carp } \\
\text { reovirus 106) }\end{array}$ & Grass carp & China, 2009 & 24.778 & $11 / 11$ & KC201166-KC201176 & [97] \\
\hline 7 & $\begin{array}{l}\text { GCRV-HeNan988 (Grass } \\
\text { carp reovirus-Henan988) }\end{array}$ & Grass carp & China, 2009 & 24.780 & $11 / 11$ & KC847320-KC847330 & [97] \\
\hline 8 & $\begin{array}{l}\text { GCRV918 (Grass carp } \\
\text { reovirus 918) }\end{array}$ & Grass carp & China, 2010 & 24.780 & $11 / 11$ & KC201177-KC201187 & [97] \\
\hline 9 & $\begin{array}{l}\text { GCRV-109 (Grass carp } \\
\text { reovirus-109) }\end{array}$ & Grass carp & China, 2014 & 24.625 & $11 / 11$ & KC201177-KC201187 & {$[90]$} \\
\hline 10 & $\begin{array}{l}\text { GCRV-GD108 (Grass carp } \\
\text { reovirus-GD108) }\end{array}$ & Grass carp & China, 2009 & 24.703 & $11 / 12$ & HQ231198-HQ231208 & [88] \\
\hline 11 & $\begin{array}{l}\text { HGDRV (GCRV 104) } \\
\text { (Hubei grass carp disease } \\
\text { reovirus) }\end{array}$ & Grass carp & China, 2009 & 23.706 & $11 / 12$ & JN967629-JN967639 & [89] \\
\hline 12 & PRV(Piscine reovirus) & Atlantic salmon & Norway, 2012 & 23.320 & $10 / 11$ & GU994013-GU994022 & [95] \\
\hline 13 & $\begin{array}{l}\text { GSRV (Golden shiner } \\
\text { reovirus) }\end{array}$ & Golden shiner & America, 1979 & 23.695 & $11 / 12$ & AF403398-AF403408 & [93] \\
\hline 14 & $\begin{array}{l}\text { CSRV (CHSRV) (chum } \\
\text { salmon reovirus) }\end{array}$ & Salmon & Japan, 1981 & 23.015 & $11 / 12$ & AF418294-AF418304 & [93] \\
\hline 15 & $\begin{array}{l}\text { SMReV (Turbot Scoph- } \\
\text { thalmus maximus reovirus) }\end{array}$ & Turbot & China, 2012 & 24.042 & $11 / 12$ & НМ989930-HМ989940 & [94] \\
\hline
\end{tabular}


(not 11 as in all recognized aquareoviruses) and an outer-fiber protein that is present in most members of the $\mathrm{Or}$ thoreovirus genus [96,97]. Moreover, phylogenetic evidence of long distance dispersal and transmission has been revealed by comparing the protein coding sequences $\mathrm{S} 1, \mathrm{~S} 2$ and S4 in Piscine reovirus genomic segments between farmed and wild Atlantic salmon [98].

As an ideal model system for studying the cell entry mechanism used by nonenveloped viruses, single-particle cryo-electron microscopy has been used to observe the $3.3 \AA$ structure of the primed, infectious subvirion GCRV particle, thereby providing structural insight into the coupling of virion assembly $[99,100]$. Additionally, new insight into the mechanisms of viral factory formation and pathogenesis of aquareoviruses has been acquired from functional studies on aquareoviral genes where NS80, a nonstructural protein of fish reovirus, has been confirmed to be crucial for recruiting viral components to form aquareoviral factories [101].

\section{Rhabdovirus genomes}

Rhabdoviruses are a group of enveloped, single-stranded, negative-sense RNA viruses. The Rhabdoviridae family includes the following nine genera: Cytorhabdovirus, Ephemerovirus, Lyssavirus, Novirhabdovirus, Nucleorhabdovirus, Perhabdovirus, Sigmavirus, Tibrovirus and Vesiculovirus [20]. All known fish rhabdoviruses have been assigned to the following three genera: Vesiculovirus, Novirhabdovirus and Perhabdovirus [102,103].

Fish rhabdoviruses can cause severe hemorrhagic septicemia in freshwater and marine fish. In the last 10 years, virologists isolated and identified the following rhabdoviruses from aquaculture fish: Siniperca chuatsi rhabdovirus [104], Scophthalmus maximus rhabdovirus [105,106], Paralichthys olivaceus rhabdovirus [107], Monopterus albus rhabdovirus [108], snakehead rhabdovirus [109,110], Hirame rhabdovirus [111], and pike fry rhabdovirus [112]. Spring viremia of carp virus (SVCV), an earlier identified rhabdovirus, causes infectious hemorrhagic septicemia in common carp (Cyprinus carpio) [102,113]. Perch rhabdovirus causes lethal hemorrhagic disease in different farmed species of perch, bass, grayling and trout [114,115]. Viral hemorrhagic septicemia virus (VHSV) and infectious haematopoietic necrosis virus (IHNV) are two typical rhabdoviruses of the Novirhabdovirus genus. VHSV is a viral pathogen affecting both wild and cultured fish worldwide; infected species include salmon, trout, cod, herring, sole, catfish, pike, turbot, and flounder, among others [115]. IHNV causes severe losses to the salmon fish industry in the USA and Canada, and many other countries in Asia and Europe [18].

IHNV is the first fish rhabdovirus that has had its complete genome sequenced [116]. Currently, more than 100 fish rhabdovirus genomes have been completely sequenced, and over 80 of them are from different VHSV isolates or strains (Table 3). Fish rhabdovirus genomes are negative-sense, single-stranded RNA molecules, and their sizes range from 11 to $16 \mathrm{~kb}$. In fish rhabdoviruses of the Vesiculovirus genus, such as SVCV, pike fry rhabdovirus, Siniperca chuatsi rhabdovirus, and Scophthalmus maximus rhabdovirus, their genomes encode the following five proteins: nucleoprotein $(\mathrm{N})$, phosphoprotein $(\mathrm{P})$, matrix protein $(\mathrm{M})$, glycoprotein $(\mathrm{G})$, and RNA-dependent RNA polymerase (L) in the order 3'-N-P-M-G-L-5', whereas in fish rhabdoviruses of the Novirhabdovirus genus, such as VHSV, IHNV, Hirame rhabdovirus, snakehead rhabdovirus and Paralichthys olivaceus rhabdovirus, their genomes encode the following six proteins: N, P, M, G, non-virion protein (NV), and L, in the order 3'-N-P-M-G-NV-L-5'. In comparison with Vesiculovirus genus members, novirhabdoviruses possess an additional NV gene [107].

Because of their small genomes, short generation times and rapid mutation rates, fish rhabdoviruses, especially VHSV and IHNV, have been extensively used to analyze their evolutionary patterns, genetic diversity and biogeography of the numerous variants. Pierce and Stepien [117] evaluated the phylogenetic and biogeographic relationships of various VHSV isolates by comparing their corresponding genomic sequences, and depicted an evolutionary history of relatively rapid population diversifications in star-like patterns, following a quasispecies model. Furthermore, He et al. [118] applied the Bayesian coalescent method to the time-stamped entire coding sequences of each VHSV gene. Through age calculations on six genes, the first bifurcation event of the isolates they analyzed was estimated to have occurred within the last 300 years. Additionally, comprehensive phylogenetic analyses have been performed by comparing the corresponding gene sequences of worldwide VHSV or IHNV isolates [114,119,120].

In fish rhabdoviruses of the Vesiculovirus genus, SVCV genomes, which can be classified into different clades and genogroups, have been described as possessing high levels of diversity and plasticity [121,122]. Recently, Xiao et al. [123] performed recombination analysis of all known complete SVCV genomic sequences, and found evidence of homologous recombination in these genomes. This finding sheds light on recombination and the evolutionary process in various isolates of fish rhabdoviruses.

To allow functional studies to be conducted on fish rhabdovirus genes, several IHNV-VHSV chimeric recombinant viruses were constructed to allow the researchers to identify virulence genes through reverse genetics. Through comparative challenge experiments in rainbow trout fingerlings, recombinant IHNV gained higher virulence following substitution of the $\mathrm{G}$ gene with that of each individual VHSV strain [124]. Additionally, an in vivo superinfection assay has recently been developed to examine the role of virulence in IHNV of fish rhabdoviruses [125]. 
Table 3 Known fish rhabdoviruses and their genomes

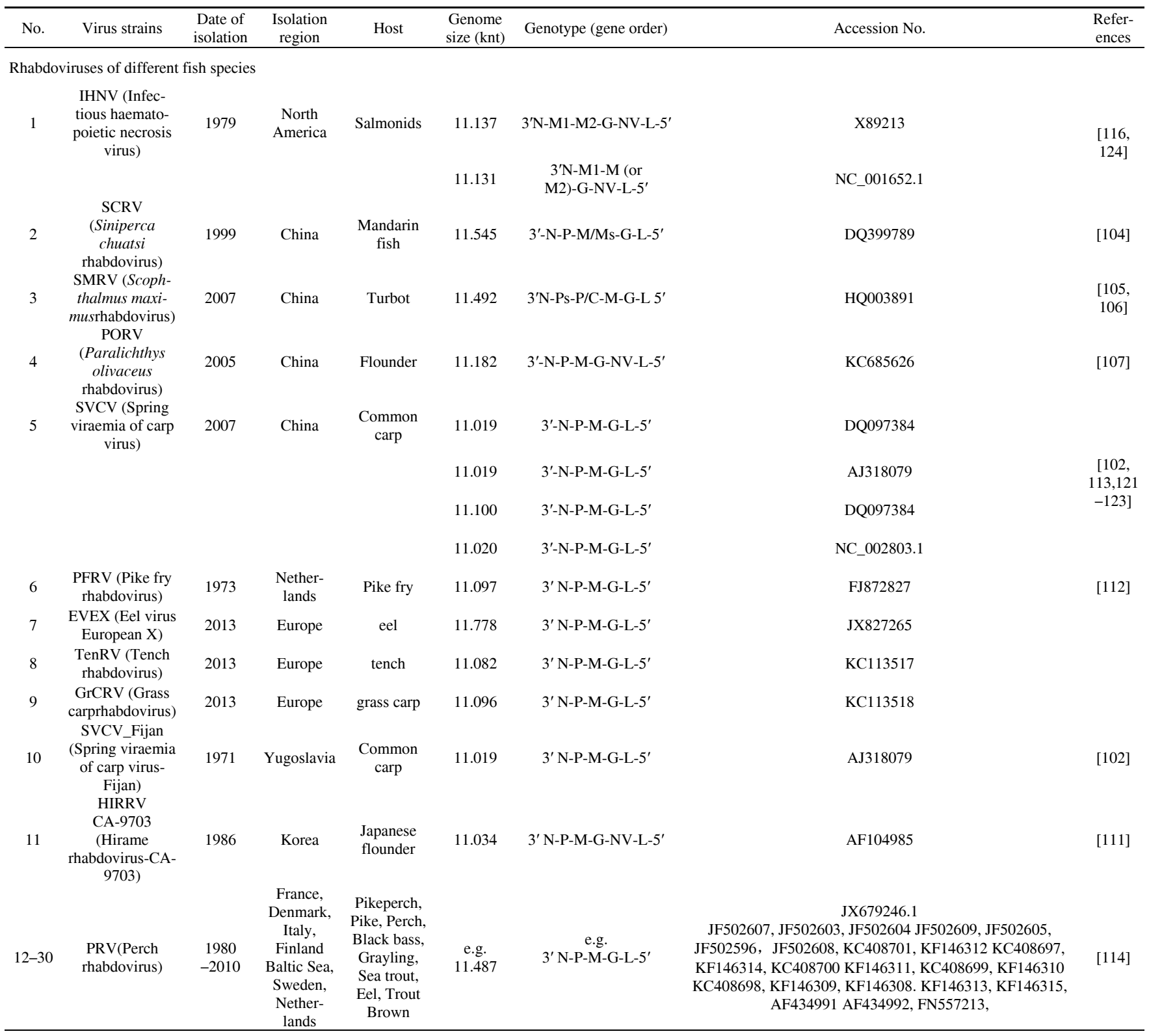

Viral hemorrhagic septicemia virus (VHSV) from different fish species

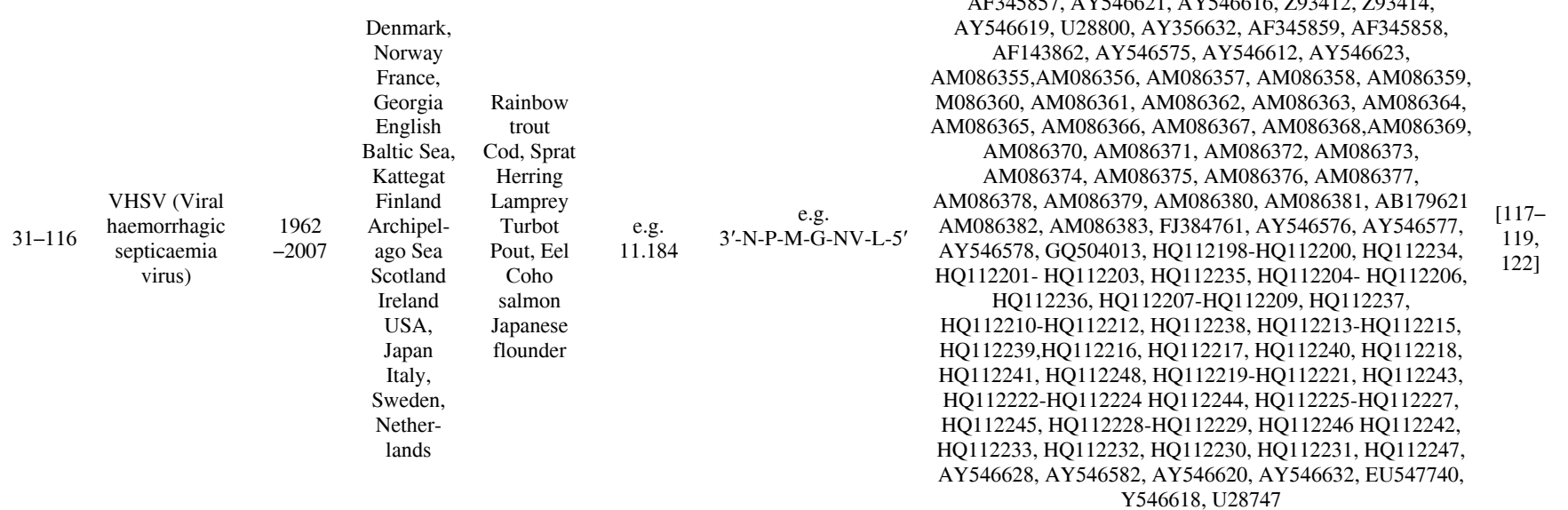




\section{Herpesvirus genomes}

Herpesviruses are enveloped viruses containing large, double-stranded, linear DNA genomes. They are host-specific pathogens, and are wide spread among vertebrates such as mammals, birds, amphibians and fish [126]. After two new virus families, namely, Alloherpesviridae (incorporating fish and frog herpesviruses) and Malacoherpesviridae (containing mollusks) were recognized in 2009, the Herpesvirales order includes the following three families: Herpesviridae (containing mammals and birds), Alloherpesviridae, and Malacoherpesviridae. The Alloherpesviridae family is divided into the following four genera: Batrachovirus, Cyprinivirus, Ictalurivirus, and Salmonivirus [20]. The Cyprinivirus genus contains four species: three of them, cyprinid herpesvirus 1 (CyHV-1), cyprinid herpesvirus 2 (CyHV-2), and cyprinid herpesvirus 3 (CyHV-3), are associated with common carp or goldfish, while one of them, anguillid herpesvirus 1 (AngHV1), is associated with freshwater eels [127,128].

Cyprinid herpesviruses have been reported to cause serious mortality in common carp and crucian carp [129]. CyHV-1 is the cause of carp pox, CyHV-3 is fatal in carp and koi fish, and CyHV-2 is the etiological agent of herpesviral hematopoietic necrosis disease in common carp, goldfish, crucian carp, and gibel carp [130]. Through use of bioluminescence imaging, the skin covering a fish's fins and body has been shown to be the major port of entry for cyprinid herpesviruses [131]. Tissue culture and RT-PCR testing results indicate that herpesviruses may become latent in leukocytes and other tissues following a primary infection, and that they can be reactivated from latency by temperature stress [132]. Recently, B cells have been identified as a major site where CyHV-3 can become latent [133].

CyHV-3 has been observed to cause significant morbidity and mortality in koi and common carp. The pathological signs include epidermal abrasions, excess mucus production, necrosis of gills and internal organs, and lethargy. CyHV-3 propagates well in the intestines and kidneys, and high numbers of infectious viruses can be observed in the droppings of infected fish [134]. Several primary culture cell lines can be used to propagate cyprinid herpesviruses and for isolating these etiologic agents of disease [135].

So far, the complete genomes of 11 herpesviruses have been sequenced from aquatic animals, nine of which are members of the Alloherpesviridae family, while two are members of the Malacoherpesviridae family. The genomes of these herpesviruses range in size from about $134.2 \mathrm{~kb}$ for the smallest (Ictalurid herpesvirus 1) to about $295.2 \mathrm{~kb}$ for the largest (Koi herpesvirus-J); their potential numbers of genes range from 77 to 163 (Table 4).

The complete genome sequences of five cyprinid herpesviruses, the diseases of which are fatal in common carp, koi carp, goldfish, crucian carp, and gibel carp [130] have been reported. These genomes are characterized by a unique region flanked at each terminus by a sizeable direct repeat. About 120 orthologous genes are shared by these cyprinid herpesviruses, and 55 of them also share sequence conser-

Table 4 Known herpesviruses of aquatic animals and their genomes

\begin{tabular}{|c|c|c|c|c|c|c|c|}
\hline No. & Genus/strain & Host/symptom & $\begin{array}{c}\text { Isolation } \\
\text { region/time }\end{array}$ & $\begin{array}{l}\text { Genome size } \\
(\mathrm{kb})\end{array}$ & $\begin{array}{l}\text { Potential } \\
\text { ORFs }\end{array}$ & $\begin{array}{l}\text { Accession } \\
\text { No. }\end{array}$ & References \\
\hline \multicolumn{8}{|c|}{ 1loherpesviridae } \\
\hline 1 & $\begin{array}{c}\text { Ictalurivirus/Ictalurid } \\
\text { herpesvirus } 1 \text { (IcHV-1) }\end{array}$ & Channel catfish & USA, 1971 & 134,226 & 77 & M75136 & {$[138,139]$} \\
\hline 2 & $\begin{array}{c}\text { Ictalurivirus/Anguillid } \\
\text { herpesvirus } 1 \text { (AngHV-1) }\end{array}$ & Eels (Anguilla) & $\begin{array}{l}\text { Netherlands, } \\
1996\end{array}$ & 248.526 & 134 & FJ940765 & {$[140-142]$} \\
\hline 3 & $\begin{array}{l}\text { Cyprinivirus/Cyprinid } \\
\text { herpesvirus1 (CyHV-1) }\end{array}$ & $\begin{array}{c}\text { Common carp (Cyprinus carpio) and koi carp } \\
\text { (a variety of Cyprinus carpio)/carp pox, } \\
\text { papilloma }\end{array}$ & Japan, 1985 & 291,144 & 143 & JQ815363 & \multirow[t]{2}{*}[91,128]{} \\
\hline 4 & $\begin{array}{l}\text { Cyprinivirus/Cyprinid } \\
\text { herpesvirus } 2 \text { (CyHV-2) }\end{array}$ & $\begin{array}{l}\text { Goldfish (Carassius auratus)/goldfish hema- } \\
\text { topoietic necrosis }\end{array}$ & Japan, 1992 & 290,304 & 154 & JQ815364 & \\
\hline 5 & $\begin{array}{c}\text { Cyprinivirus/Cyprinid } \\
\text { herpesvirus } 3 \text { (CyHV-3) } \\
\text { KHV-U }\end{array}$ & \multirow{3}{*}{$\begin{array}{c}\text { Koi and Cyprinus carpio/Bleeding gills, sunken } \\
\text { eyes, pale patches or skin blistering }\end{array}$} & USA, 2003 & 295.146 & 163 & DQ657948 & \multirow{3}{*}{ [136] } \\
\hline 6 & KHV-J & & Japan, 2004 & 295,271 & 156 & AP008984 & \\
\hline 7 & KHV-I & & Israel, 1998 & 295,138 & & DQ177346 & \\
\hline 9 & $\begin{array}{c}\text { Batrachoviru/Ranid her- } \\
\text { pesvirus } 2(\text { RaHV-2) Frog } \\
\text { virus } 4\end{array}$ & $\begin{array}{c}\text { Leopard frog, Rana pipiens/Renal carcinoma or } \\
\text { Lucke tumor }\end{array}$ & $\begin{array}{l}\text { North } \\
\text { American, } \\
1964\end{array}$ & 231,801 & 147 & DQ665652 & {$[138,139]$} \\
\hline \multicolumn{8}{|c|}{ Malacoherpesviridae } \\
\hline 10 & $\begin{array}{l}\text { Ostreavirus/Oyster } \\
\text { herpesvirus OsHV1 }\end{array}$ & Oyster & $\begin{array}{l}\text { New Zea- } \\
\text { land, } 1995\end{array}$ & 207,439 & 124 & AY509253 & {$[128]$} \\
\hline 11 & $\begin{array}{l}\text { Ostreavirus/Acute viral } \\
\text { necrosis virus (AVNV) }\end{array}$ & Chinese scallop Chlamys farreri & China, 1998 & 210,993 & 123 & GQ153938 & [144] \\
\hline
\end{tabular}


vation with AngHV1 of the Cyprinivirus genus. Significantly, only 12 genes were found to be conserved convincingly in all the sequenced alloherpesviruses [136-138].

Ictalurid herpesvirus 1 is the type species of the Ictalurivirus genus, and is the first fish herpesvirus for which the complete genome is known [139]. AngHV1 also frequently causes fatal disease in freshwater eels. After complete genome sequencing [140] and deep-sequencing of the AngHV1 transcriptome [141] were finalized, a genomewide transcription analysis was performed using reverse transcription quantitative PCR, and a temporal regulation fashion similar to mammalian herpesviruses was observed in this fish herpesvirus [142].

Chelonid herpesvirus 5 is closely related to fibropapillomatosis, a neoplastic disease of marine turtles. Its genomic sequence has been shown to be largely collinear with the genomes of typical alphaherpesviruses [143]. In addition, the complete genome sequence of the acute viral necrosis virus, which belongs to the Malacoherpesviridae family, has also been reported recently [144].

In recent years, after cyprinid herpesvirus disease became widely reported in the world, (especially in China) [145-147], numerous studies on cyprinid herpesviruses and identification of immune-related genes have been conducted [148-150]. It is envisaged, therefore, that new insight and better understanding of these cyprinid herpesviruses will emerge and lead to efficient antiviral approaches being developed in the near future.

\section{Virus-host interactions in aquatic animals}

The diverse viruses discussed above are serious pathogens of aquatic animals, especially those used in aquaculture. To understand their pathogenetic mechanisms and thereby provide protective strategies again them, some significant experimental methods and high-throughput technologies such as transcriptomics and proteomics have been recently used to gain better knowledge of these viruses and their hosts. Such studies have greatly expanded our knowledge about the innate and acquired immune systems of aquatic animals [151-155]. In China especially, comparative immunological studies of aquaculture animals have flourished over the last 10 years, financial support for research in this area has increased, and progress in this field has been reported in several reviews [156-162]. Figure 2 is a schematic diagram outlining the interactions occurring between the diverse range of viruses discussed herein and their aquatic hosts. The diagram also shows how innate and acquired immunity, as well as related factors such as physical barriers, operate in aquaculture animals under attack by pathogenic viruses.

As shown in Figure 2, when viruses, such as iridoviruses, herpesviruses, reoviruses, or rhabdoviruses attempt to enter a host cell, they first meet physical barriers on the skin and interact with a continuous layer of mucus and the complex regulatory networks that control skin immunity [163-166]. After such viruses pass the first line of defense and enter the host cell, the infected cell immediately initiates a series of innate immune responses; these include an inflammatory

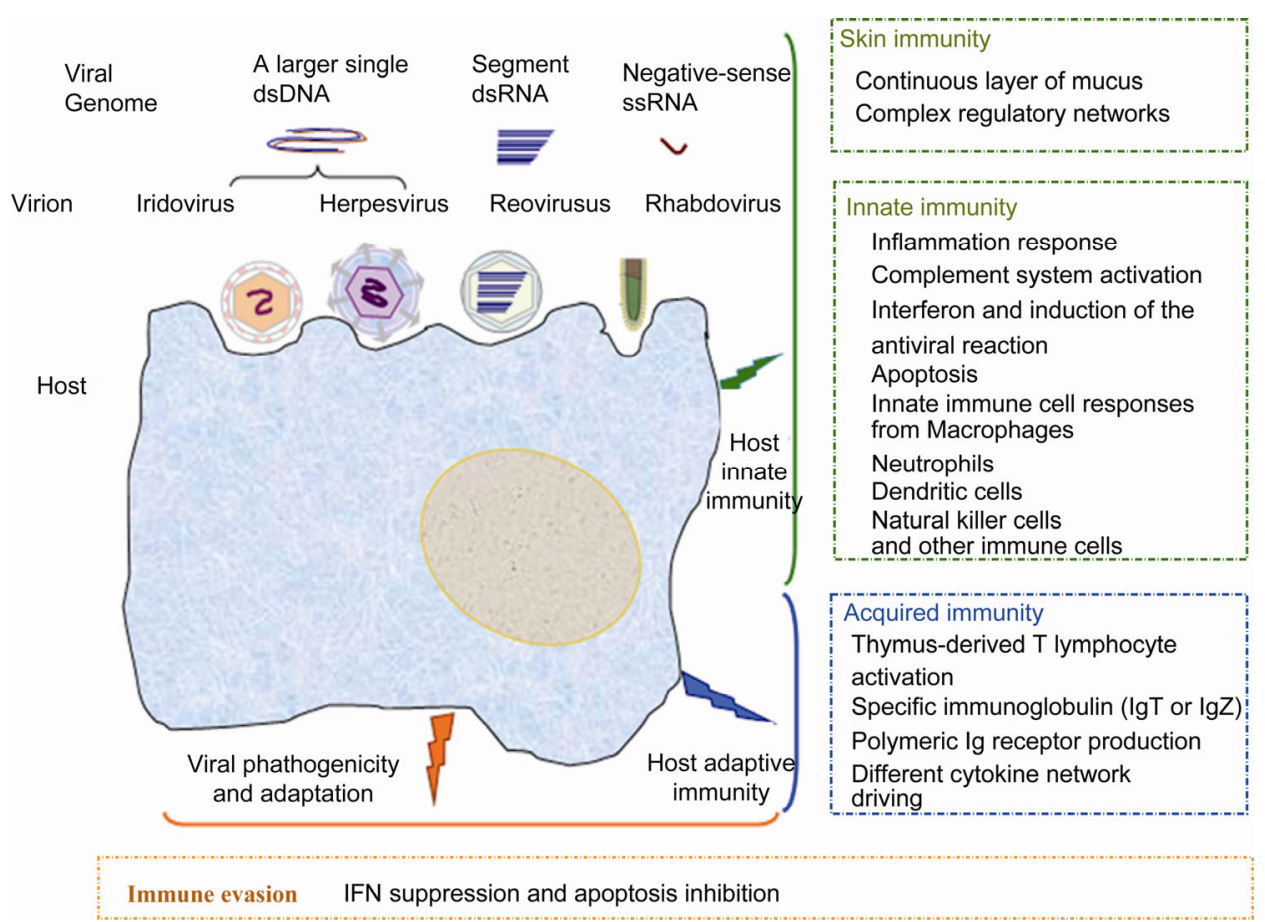

Figure 2 Schematic diagram illustrating the types of interactions that can occur between viruses and a host cell from an aquatic animal. 
response, complement system activation, interferon production, induction of antiviral reactions, cell apoptosis, and innate immune cell responses from macrophages, neutrophils, dendritic cells, natural killer and other immune cells that prevent viral replication and inhibit virus propagation $[153,156,167]$. Subsequently or concurrently, acquired (adaptive) immune responses, such as thymus-derived $\mathrm{T}$ lymphocyte activation, specific immunoglobulins (IgT or IgZ), polymeric Ig receptor production, and differential cytokine network activation, amongst others, enables collaboration between the cellular and humoral immune systems leading to destruction of the invading viruses [168-171]. Additionally, some aquatic viruses have developed immune evasion mechanisms and strategies to combat host immune systems through IFN suppression and apoptosis inhibition; such viruses have increased pathogenicity and have acquired the ability to cross species barriers in their transmission $[153,167,172]$.

\section{Conclusion and outlook}

Over the last decade, a large number of diverse pathogenic viruses, such as iridoviruses, herpesviruses, reoviruses, and rhabdoviruses, have been identified from aquaculture and natural aquatic animals, and many of their genomes have been completely sequenced. Comparative genomic and phylogenetic analyses have provided new insight into the origins of these viruses, as well as the different routes that have led to genetic change and evolutionary processes, and cross-species transmission mechanisms. Additionally, functional studies on genes have yielded crucial information about viral factory formation and pathogenesis in these viruses. Along with their genome architectures and genetic characterization, the interactions between these viruses and their aquatic animal hosts have become an important focus in aquaculture. Finally, significant progress has been made in understanding the following: (i) the molecular mechanisms underlying virus-host interactions [173-176], (ii) innate antiviral immune responses in fish, and (iii) gene identification in the fish interferon system [177-179]. Armed with this knowledge, it is hoped that new drugs and strategies to protect aquaculture animals against pathogenic viruses will be developed in the near future.

The authors declare they have no conflict of interest.

This work was supported by grants from the National Natural Science Foundation of China (31430091), the National Key Basic Research Program (2010CB126303), and the Project of State Key Laboratory of Freshwater Ecology and Biotechnology (2011FBZ12).

1 Cressey D. Aquaculture: future fish. Nature, 2009, 458: 398-400

2 Bostock J, McAndrew B, Richards R. Aquaculture: global status and trends. Phil Trans R Soc B, 2010, 365: 2897-2912
3 Gui JF, Zhu ZY. Molecular basis and genetic improvement of economically important traits in aquaculture animals. Chin Sci Bull, 2012, 57: 1751-1760

4 Fisheries and Administration Agency, Ministry of Agriculture. China Fishery Statistical Yearbook. Beijing: China Agriculture Press, 2014

5 Tacon A, Metian M. Global overview on the use of fish meal and fish oil in industrially compounded aquafeeds: trends and future prospects. Aquaculture, 2008, 285: 146-158

6 Daszak P, Cunningham AA, Hyatt AD. Emerging infectious diseases of wildlife-threats to biodiversity and human health. Science, 2000, 287: 443-449

7 Walker PJ, Winton Jr. Emerging viral diseases of fish and shrimp. Vet Res, 2010, 41: 51

8 Collins JP, Crump ML. Extinction in Our Times: Global Amphibian Decline. New York: Oxford University Press, 2009

9 Fisher MC. Silent springs: why are all the frogs "croaking"'? PLoS Biol, 2009, 7: e1000198

10 Echaubard P, Leduc J, Pauli B, Chinchar VG, Robert J, Lesbarrères D. Environmental dependency of amphibian-ranavirus genotypic interactions: evolutionary perspectives on infectious diseases. Evol Appl, 2014, doi: 10.1111/eva.12169

11 Lips KR, Brem F, Brenes R, Reeve JD, Alford RA, Voyles J, Carey C, Pessier AP, Livo L, Collins JP. Emerging infectious disease and the loss of biodiversity in a Neotropical amphibian community. Proc Natl Acad Sci USA, 2006, 103: 3165-3170

12 Chinchar VG, Hyatt A, Miyazaki T, Williams T. Family Iridoviridae: poor viral relations no longer. Curr Top Microb Imm, 2009, 328: 123-170

13 Une Y, Sakuma A, Matsueda H, Nakai K, Murakami M. Ranavirus outbreak in North American bullfrogs (Rana catesbeiana), Japan, 2008. Emerg Infect Dis, 2009, 15:1146-1147

14 Hyatt AD, Gould AR, Zupanovic Z, Cunningham AA, Hengstberger S, Whittington RJ, Kattenbelt J, Coupar BE. Comparative studies of piscine and amphibian iridoviruses. Arch Virol, 2000, 145: 301-331

15 Kik M, Martel A, Spitzen-van der Sluijs A, Pasmans F, Wohlseind P, Grönea A, Rijksa JM. Ranavirus-associated mass mortality in wild amphibians, The Netherlands, 2010: A first report. Vet J, 2012, 190: 284-286

16 Zhang QY, Gui JF. Aquatic Virology. Beijing: Higher Education Press, 2008

17 Burnell G, Allan G. New technologies in aquaculture: Improving production efficiency, quality and environmental management. Cambridge: Woodhead Publishing Limited, 2009

18 Crane M, Hyatt A. Viruses of fish: an overview of significant pathogens. Viruses, 2011, 3: 2025-2046

19 Zhang QY, Gui JF. Atlas of Aquatic Viruses and Viral Diseases. Beijing: Science Press, 2012

20 King AMQ, Adams MJ, Carstens EB, Lefkowitz EJ, eds. Virus Taxonomy: Classification and Nomenclature of Viruses: Ninth Report of the International Committee on Taxonomy of Viruses. San Diego: Elsevier Academic Press, 2011

21 Williams T, Barbosa-Solomieu V, Chinchar VG. A decade of advances in iridovirus research. Adv Virus Res, 2005, 65: 173-248

22 Tidona CA, Darai G. The complete DNA sequence of lymphocystis disease virus. Virology, 1997, 230: 207-216

23 Zhang QY, Xiao F, Xie J, Li ZQ, Gui JF. Complete genome sequence of lymphocystis disease virus isolated from China. J Virol, 2004, 78: 6982-6994

24 Bandín I, Dopazo CP. Host range, host specificity and hypothesized host shift events among viruses of lower vertebrates. Vet Res, 2011, 42: 67

25 Whittington RJ, Becker JA, Dennis MM. Iridovirus infections in finfish-Critical review with emphasis on ranaviruses. J Fish Dis, 2010, 33: 95-122

26 Robert J, George E, De Jesus Andino F, Chen G. Waterborne infectivity of the Ranavirus frog virus 3 in Xenopus laevis. Virology, 2011, 417: 410-417

27 Geng Y, Wang KY, Zhou ZY, Li CW, Wang J, He M, Yin ZQ, Lai WM. First report of a ranavirus associated with morbidity and mor- 
tality in farmed Chinese giant salamanders (Andrias davidianus). J Comp Pathol, 2011, 145: 95-102

28 Dong W, Zhang X, Yang C, An J, Qin J, Song F, Zeng W. Iridovirus infection in Chinese giant salamanders, China, 2010. Emerg Infect Dis, 2011, 17: 2388-2389

29 Brenes R, Gray MJ, Waltzek TB, Wilkes RP, Miller DL. Transmission of ranavirus between ectothermic vertebrate hosts. PLoS One, 2014, 9: e92476

30 Schloegel LM, Daszak P, Cunningham AA, Speare R, Hill B. Two amphibian diseases, chytridiomycosis and ranaviral disease, are now globally notifiable to the World Organization for Animal Health (OIE): an assessment. Dis Aquat Organ, 2010, 92: 101-108

31 Miller D, Gray M, Storfer A. Ecopathology of ranaviruses infecting amphibians. Viruses, 2011, 3: 2351-2373

32 Chinchar V. Ranavirus (family Iridoviridae): emerging cold-blooded killers. Arch Virol, 2002, 147: 447-470

33 Chinchar VG, Waltzek TB. Ranaviruses: not just for frogs. PLoS Pathog, 2014, 10: e1003850

34 Stuart SN, Chanson JS, Cox NA, Young BE, Rodrigues ASL, Fischman DL, Waller RW. Status and trends of amphibian declines and extinctions worldwide. Science, 2004, 306: 1783-1786

35 Morrison EA, Garner S, Echaubard P, Lesbarrères D, Kyle CJ, Brunetti CR. Complete genome analysis of a frog virus 3 (FV3) isolate and sequence comparison with isolates of differing levels of virulence. Virol J, 2014, 11: 46

36 Mavian C, López-Bueno A, Fernández Somalo MP, Alcamí A, Alejo A. Complete genome sequence of the European sheatfish virus. J Virol, 2012a, 86: 6365-6366

37 Jancovich JK, Bremont M, Touchman JW, Jacobs BL. Evidence for multiple recent host species shifts among the Ranaviruses (family Iridoviridae) J Virol, 2010, 84: 2636-2647

38 Lei XY, Ou T, Zhu RL, Zhang QY, Zhang QY. Sequencing and analysis of the complete genome of Rana grylio virus (RGV). Arch Virol, 2012, 157: 1559-1564

39 Tan WG, Barkman TJ, Chinchar VG, Essani, K. Comparative genomic analyses of frog virus 3, type species of the genus Ranavirus (family Iridoviridae). Virology, 2004, 323: 70-84

40 Zhang QY, Li ZQ, Gui JF. Studies on morphogenesis and cellular interactions of Rana grylio virus in an infected fish cell line. Aquaculture, 1999, 175: 185-197

41 Zhang QY, Xiao F, Li ZQ, Gui JF. Comparison of sequence homology of major capsid protein gene of Rananvirus frog virus 3 and $R a$ na grylio virus isolates from China. Chin J Virol, 2001, 17: 372-374

42 Zhang QY, Xiao F, Li ZQ, Gui JF, Mai J, Chinchar VG. Characterization of an iridovirus from the cultured pig frog (Rana grylio) with lethal syndrome. Dis Aquatic Organ, 2001, 48: 27-36

43 Zhang QY, Zhao Z, Xiao F, Li ZQ, Gui JF. Molecular characterization of three Rana grylio virus (RGV) isolates and Paralichthys olivaceus lymphocystis disease virus (LCDV-C) in iridoviruses. Aquaculture, 2006, 251: 1-10

44 Jancovich JK, Davidson EW, Morado JF, Jacobs BL, Collins JP. Isolation of a lethal virus from the endangered tiger salamander Ambystoma tigrinum stebbinsi. Dis Aquat Org, 1997, 31: 161-167

45 Jancovich JK, Mao J, Chinchar VG, Wyatt C, Case ST, Kumar S, Valente G, Subramanian S, Davidson EW, Collins JP, Jacobs BL. Genomic sequence of a ranavirus (family Iridoviridae) associated with salamander mortalities in North America. Virology, 2003, 316: 90-103

46 Qin QW, Lam TJ, Sin YM, Shen H, Chang SF, Ngoh GH, Chen CL. Electron microscopic observations of a marine fish iridovirus isolated from brown-spotted grouper, Epinephelus tauvina. J Virol Method, 2001, 98: 17-24

47 Song WJ, Qin QW, Qiu J, Huang CH, Wang F, Hew CL. Functional genomics analysis of Singapore grouper iridovirus: complete sequence determination and proteomic analysis. J Virol, 2004, 78: 12576-12590

48 Huang Y, Huang X, Liu H, Gong J, Ouyang Z, Cui H, Cao J, Zhao Y, Wang X, Jiang Y, Qin Q. Complete sequence determination of a novel reptile iridovirus isolated from soft-shelled turtle and evolu- tionary analysis of Iridoviridae. BMC Genomics, 2009, 10: 224

49 Tsai CT, Ting JW, Wu MH, Wu MF, Guo IC, Chang CY. Complete genome sequence of the grouper iridovirus and comparison of genomic organization with those of other iridoviruses. J Virol, 2005, 79: 2010-2023

50 He JG, Lu L, Deng M, He HH, Weng SP, Wang XH, Zhou SY, Long QX, Wang XZ, Chan SM. Sequence analysis of the complete genome of an iridovirus isolated from the tiger frog. Virology, 2002, 292: 185-197

51 Mavian C, López-Bueno A, Balseiro A, Casais R, Alcamí A, Alejo A. The genome sequence of the emerging common midwife toad virus identifies an evolutionary intermediate within ranaviruses. J Virol, 2012b, 86: 3617-3625

52 Chen ZY, Gui JF, Gao XC, Pei C, Hong YJ, Zhang QY. Genome architecture changes and major gene variations of Andrias davidianus ranavirus (ADRV). Vet Res, 2013, 44: 101

53 Zhou ZY, Geng Y, Liu XX, Ren SY, Zhou Y. Characterization of a ranavirus isolated from the Chinese giant salamander (Andrias davidianus, Blanchard, 1871) in China. Aquaculture, 2013, 384: 66-73

54 Wang N, Zhang M, Zhang L, Jing H, Jiang Y, Wu S, Lin X. Complete genome sequence of a ranavirus isolated from Chinese giant salamander (Andrias davidianus). Genome Announc, 2014, 2: e01032-13

55 Li W, Zhang X, Weng S, Zhao G, He J, Dong C. Virion-associated viral proteins of a Chinese giant salamander (Andrias davidianus) iridovirus (genus Ranavirus) and functional study of the major capsid protein (MCP). Vet Microbl, 2014, 172: 129-139

56 Darai G, Delius H, Clarke J, Apfel H, Schnitzler P, Flügel RM. Molecular cloning and physical mapping of the genome of fish lymphocystis disease virus. Virology, 1985, 146: 292-301

57 Zhang QY, Ruan HM, Li ZQ, Yuan XP, Gui JF. Infection and propagation of lymphocystis virus isolated from the cultured flounder Paralichthys olivaceus in grass carp cell lines. Dis Aquatic Org, 2003, 57: 27-34

58 Xu L, Feng J, Huang Y. Identification of lymphocystis disease virus from paradise fish Macropodus opercularis (LCDV-PF). Arch Virol, 2014, 159: 2445-2449

59 Huang X, Huang Y, Xu L, Wei S, Ouyang Z, Feng J, Qin Q. Identification and characterization of a novel lymphocystis disease virus isolate from cultured grouper in China. J Fish Dis, 2014, 10, doi: $10.1111 /$ jfd. 12244

60 He JG, Deng M, Weng SP, Li Z, Zhou SY, Long QX, Wang XZ, Chan SM. Complete genome analysis of the mandarin fish infectious spleen and kidney necrosis iridovirus. Virology, 2001, 291: 126-139

61 Jeong JB, Jun LJ, Yoo MH, Kim MS, Komisar JL, Jeong HD. Characterization of the DNA nucleotide sequences in the genome of red sea bream iridoviruses isolated in Korea. Aquaculture, 2003, 220: 119-133

62 Do JW, Moon CH, Kim HJ, Ko MS, Kim SB, Son JH, Kim JS, An EJ, Kim MK, Lee SK, Han MS, Cha SJ, Park MS, Park MA, Kim YC, Kim JW, Park JW. Complete genomic DNA sequence of rock bream iridovirus. Virology, 2004, 325: 351-363

63 Ao JQ, Chen XH. Identification and characterization of a novel gene encoding an RGD-containing protein in large yellow croaker iridovirus. Virology, 2006, 355: 213-222

64 Shi CY, Jia KT, Yang B, Huang J. Complete genome sequence of a megalocytivirus (family Iridoviridae) associated with turbot mortality in China. Virol J, 2010, 7: 159

65 Lü L, Zhou SY, Chen C, Weng SP, Chan SM, He JG. Complete genome sequence analysis of an iridovirus isolated from the orange-spotted grouper, Epinephelus coiodes. Virology, 2005, 339: 81-100

66 Zhang BC, Zhang M, Sun BG, Fang Y, Xiao ZZ, Sun L. Complete genome sequence and transcription profiles of the rock bream iridovirus RBIV-C1. Dis Aquat Org, 2013, 104: 203-214

67 Eaton HE, Metcalf J, Penny E, Tcherepanov V, Upton C, Brunetti CR. Comparative genomic analysis of the family Iridoviridae: re-annotating and defining the core set of iridovirus genes. Virol J, 2007, 4: 11 
68 Abrams AJ, Cannatella DC, Hillis DM, Sawyer SL. Recent host-shifts in ranaviruses: signatures of positive selection in the viral genome. J Gen Virol, 2013, 94: 2082-2093

69 Currylow AF, Johnson AJ, Williams RN. Evidence of ranavirus infections among sympatric larval amphibians and box turtles. J Herpet, 2014, 48:117-121

70 Sun W, Huang YH, Zhao Z, Gui JF, Zhang QY. Characterization of the Rana grylio virus 3 $\beta$-hydroxysteroid dehydrogenase and its novel role in suppressing virus-induced cytopathic effect. Biochem Biophys Res Commun, 2006, 351: 44-50

71 Zhao Z, Ke F, Gui JF, Zhang QY. Characterization of an early gene encoding for dUTPase in Rana grylio virus. Virus Res, 2007, 123: $128-137$

72 Zhao Z, Shi Y, Ke F, Sun W, Gui JF, Zhang QY. Constitutive expression of thymidylate synthase from LCDV-C induces foci formation and anchorage-independent growth in fish cells. Virology, 2008, 372: 118-126

73 Zhao Z, Ke F, Huang YH, Zhao JG, Gui JF, Zhang QY. Identification and characterization of a novel envelope protein in Rana grylio virus. J Gen Virol, 2008, 89: 166-1872

74 Whitley DS, Yu K, Sample RC, Sinning A, Henegar J, Norcross E, Chinchar VG. Frog virus 3 ORF 53R, a putative myristoylated membrane protein, is essential for virus replication in vitro. Virology, 2010, 405: 448-456

75 He LB, Gao XC, Ke F, Zhang QY. A conditional lethal mutation in Rana grylio virus ORF 53R resulted in a marked reduction in virion formation. Virus Res, 2013, 177: 194-200

76 Lei XY, Ou T, Zhang QY. Rana grylio virus (RGV) 50L is associated with viral matrix and exhibited two distribution patterns. PLoS One, 2012, 7: e43033

77 He LB, Ke F, Wang J, Gao XC, Zhang QY. Rana grylio virus (RGV) envelope protein $2 \mathrm{~L}$ subcellular localization and essential roles in virus infectivity revealed by conditional lethal mutant. J Gen Virol, 2014, 95: 679-690

78 Chen G, Ward BM, Yu EK, Chinchar VG, Robert J. Improved knockout methodology reveals that Frog virus 3 mutants lacking either the $18 \mathrm{~K}$ immediate-early gene or the truncated vIF-2 alpha gene are defective for replication in vivo. J Virol, 2011, 85: 11131-11138

79 Sample R, Bryan L, Long S, Majji S, Hoskins G, Sinning A, Olivier J, Chinchar VG. Inhibition of iridovirus protein synthesis and virus replication by antisense morpholino oligonucleotides targeted to the major capsid protein, the $18 \mathrm{kDa}$ immediate-early protein, and a viral homolog of RNA polymerase II. Virology, 2007, 358: 311-320

80 Kim YS, Ke F, Lei XY, Zhu R, Zhang QY. Viral envelope protein 53R gene highly specific silencing and iridovirus resistance in fish cells by a miRNA. PLoS One, 2010, 5: e10308

81 Majji S, Thodima V, Sample R, Whitley D, Deng Y, Mao J, Chinchar VG. Transcriptome analysis of Frog virus 3, the type species of the genus Ranavirus, family Iridoviridae. Virology, 2009, 391: 293-303

82 Guo CJ, Liu D, Wu YY, Yang XB, Yang LS, Mi S, Huang YX, Luo YW, Jia KT, Liu ZY, Chen WJ, Weng SP, Yu XQ, He JG. Entry of tiger frog virus (an Iridovirus) into HepG2 cells via a pH-dependent, atypical, caveola-mediated endocytosis pathway. J Virol, 2011, 85: 6416-6426

83 Yan Y, Cui H, Jiang S, Huang Y, Huang X, Wei S, Xu W, Qin Q. Identification of a novel marine fish virus, Singapore grouper iridovirus-encoded microRNAs expressed in grouper cells by Solexa sequencing. PLoS One, 2011, 6: e19148

84 Cullen BR. microRNAs as mediators of viral evasion of the immune system. Nat Imm, 2013, 14: 205-210

85 Qiu T, Lu RH, Zhang J, Zhu ZY. Complete nucleotide sequence of the $\mathrm{S} 10$ genome segment of grass carp reovirus (GCRV). Dis Aquat Org, 2001, 44: 69-74

86 Zhang QY, Ruan HM, Li ZQ, Zhang J, Gui JF. Detection of grass carp hemorrhage virus (GCHV) from Vietnam and comparison with GCHV strain from China. High Technol Lett, 2003, 9: 7-13

87 Wang Q, Zeng W, Liu C, Zhang C, Wang Y, Shi C, Wu S. Complete genome sequence of a reovirus isolated from grass carp, indicating different genotypes of GCRV in China. J Virol, 2012, 86: 12466
88 Ye X, Tian YY, Deng GC, Chi YY, Jiang XY. Complete genomic sequence of a reovirus isolated from grass carp in China. Virus Res, 2012, 163: 275-283

89 Fan Y, Rao S, Zeng L, Ma J, Zhou Y, Xu J, Zhang H. Identification and genomic characterization of a novel fish reovirus, Hubei grass carp disease reovirus, isolated in 2009 in China. J Gen Virol, 2013, 94: 2266-2277

90 Pei C, Ke F, Chen ZY, Zhang QY. Complete genome sequence and comparative analysis of grass carp reovirus strain 109 (GCReV-109) with other grass carp reovirus strains reveals no significant correlate regional distribution. Arch Virol, 2014, 159: 2435-2440

91 Jaafar FM, Goodwin AE, Belhouchet M, Merry G, Fang Q, Cantaloube JF, Biagini P, de Micco P, Mertens PP, Attoui H. Complete characterisation of the American grass carp reovirus genome (genus Aquareovirus: family Reoviridae) reveals an evolutionary link between aquareoviruses and coltiviruses, Virology, 2008, 373: 310-321

92 Yan XY, Wang Y, Xiong LF, Jian JC, Wu ZH. Phylogenetic analysis of newly isolated grass carp reovirus. SpringerPlus, 2014, 3: 190

93 Attoui H, Fang Q, Mohd Jaafar F, Cantaloube JF, Biagini P, de Micco $\mathrm{P}$, de Lamballerie $\mathrm{X}$. Common evolutionary origin of aquareoviruses and orthoreoviruses revealed by genome characterization of Golden shiner reovirus, Grass carp reovirus, Striped bass reovirus and golden ide reovirus (genus Aquareovirus, family Reoviridae). J Gen Virol, 2002, 83: 1941-1951

94 Ke F, He LB, Pei C, Zhang QY. Turbot reovirus (SMReV) genome encoding a FAST protein with a non-AUG start site. BMC Genomics, 2011, 12: 323

95 Kibenge MJT, Iwamoto O, Wang Y, Morton A, Godoy MG, Kibenge FSB. Whole-genome analysis of piscine reovirus (PRV) shows PRV represents a new genus in family Reoviridae and its genome segment S1 sequences group it into two separate sub-genotypes. Virol J, 2013, 10: 230

96 Key T, Read J, Nibert ML, Duncan R. Piscine reovirus encodes a cytotoxic, non-fusogenic, integral membrane protein and previously unrecognized virion outer-capsid proteins. J Gen Virol, 2013, 94: 1039-1050

97 Nibert ML, Duncan R. Bioinformatics of recent aqua- and orthoreovirus isolates from fish: evolutionary gain or loss of FAST and fiber proteins and taxonomic implications. PLoS One, 2013, 8: e68607

98 Garseth ÅH, Ekrem T, Biering E. Phylogenetic evidence of long distance dispersal and transmission of piscine reovirus (PRV) between farmed and wild Atlantic salmon. PLoS One, 2013, 8: e82202

99 Zhang X, Jin L, Fang Q, Hui WH, Zhou ZH. 3.3 A cryo-EM structure of a nonenveloped virus reveals a priming mechanism for cell entry. Cell, 2010, 141: 472-482

100 Trask SD, McDonald SM, Patton JT. Structural insights into the coupling of virion assembly and rotavirus replication. Nat Rev Microbiol, 2012, 10: 165-177

$101 \mathrm{Ke} \mathrm{F}$, He LB, Zhang QY. Nonstructural protein NS80 is crucial in recruiting viral components to form aquareoviral factories. PLoS One, 2013, 8: e63737

102 Hoffmann B, Beer M, Schutze H, Mettenleiter TC. Fish rhabdoviruses: molecular epidemiology and evolution. Curr Top Microb Imm, 2005, 292: 81-117

103 Dietzgen RG, Kuzmin IV, eds. Rhabdoviruses: molecular taxonomy, evolution, genomics, ecology, host-vector interactions, cytopathology and control. Norfolk: Caister Academic Press, 2012

104 Tao JJ, Zhou GZ, Gui JF, Zhang QY. Genomic sequence of mandarin fish rhabdovirus with an unusual small non-transcriptional ORF. Virus Res, 2008, 132: 86-96

105 Zhang QY, Tao JJ, Gui L, Zhou GZ, Ruan HM, Li ZQ, Gui JF. Isolation and characterization of Scophthalmus maximus (turbot) rhabdovirus. Dis Aquat Org, 2007, 74: 95-105

106 Zhu RL, Lei XY, Ke F, Yuan XP, Zhang QY. Genome of turbot rhabdovirus exhibits unusual non-coding regions and an additional ORF that could be expressed in fish cell. Virus Res, 2011, 155: 495-505

107 Zhu RL, Zhang QY. Determination and analysis of the complete genome sequence of Paralichthys olivaceus rhabdovirus (PORV). Arch 
Virol, 2014, 159: 817-820

108 Ou T, Zhu RL, Chen ZY, Zhang QY. Isolation and identification of a lethal rhabdovirus from farmed rice field eels Monopterus albus. Dis Aquat Org, 2013, 106: 197-206

109 Ahne W, Jorgensen PEV, Olesen NJ. Serological examination of a rhabdovirus isolated from snakehead fish (Ophicephalus striatus) in Thailand with ulcerative syndrome. J Appl Ichthyol, 1988. 4:194-196

110 Zeng W, Wang Q, Wang Y, Liu C, Liang H, Fang X, Wu S. Genomic characterization and taxonomic position of a rhabdovirus from a hybrid snakehead. Arch Virol, 2014, 159: 2469-2473

111 Kim DH, Oh HK, Eou JI, Seo HJ, Kim SK, Oh MJ, Nam SW, Choi TJ. Complete nucleotide sequence of the hirame rhabdovirus, a pathogen of marine fish. Virus Res, 2005, 107: 1-9

112 Chen HL, Liu H, Liu ZX, He JQ, Gao LY, Shi XJ, Jiang YL. Characterization of the complete genome sequence of pike fry rhabdovirus. Arch Virol, 2009, 154: 1489-1494

113 Teng Y, Liu H, Lv J, Fan WH, Zhang QY, Qin QW. Characterization of complete genome sequence of the spring viremia of carp virus isolated from common carp (Cyprinus carpio) in China. Arch Virol, 2007, 152: 1457-1465

114 Talbi C, Cabon J, Baud M, Bourjaily M, de Boisséson C, Castric J, Bigarré L. Genetic diversity of perch rhabdoviruses isolates based on the nucleoprotein and glycoprotein genes. Arch Virol, 2011, 156: 2133-2144

115 Gadd T. Fish rhabdoviruses: viral haemorrhagic septicaemia virus (VHSV) and perch rhabdovirus (PRV): study of viral strains and the disease epidemiology in Finland. Helsinki, 2013

116 Schütze H, Enzmann PJ, Kuchling R, Mundt E, Niemann H, Mettenleiter TC. Complete genomic sequence of the fish rhabdovirus infectious haematopoietic necrosis virus. J Gen Virol, 1995, 76: 2519-2527

117 Pierce LR, Stepien CA. Evolution and biogeography of an emerging quasispecies: diversity patterns of the fish Viral Hemorrhagic Septicemia virus (VHSv). Mol Phylogenet Evol, 2012, 63: 327-341

118 He M, Yan XC, Liang Y, Sun XW, Teng CB. Evolution of the viral hemorrhagic septicemia virus: divergence, selection and origin. Mol Phylogenet Evol, 2014, 77: 34-40

119 Kurath G. Fish novirhabdoviruses. In: Dietzgen RG et al., eds. Rhabdoviruses: Molecular Taxonomy, Evolution, Genomics, Ecology, Host-Vector Interactions, Cytopathology and Control. Norfolk: Caister Academic Press, 2012. 89-116

120 Kolodziejek J, Schachner O, D'Lirrwald R, Durrwald R, Latif M, Nowotny N. "Mid-G" region sequences of the glycoprotein gene of Austrian infectious hematopoietic necrosis virus isolates form two lineages within European isolates and are distinct from American and Asian lineages. J Clin Microbiol, 2008, 46: 22-30

121 Miller O, Fuller FJ, Gebreyes WA, Miller O, Fuller FJ, Gebreyes WA, Lewbart GA, Shchelkunov IS, Shivappa RB, Joiner C, Woolford G, Stone DM, Dixon PF, Raley ME, Levine JF. Phylogenetic analysis of spring virema of carp virus reveals distinct subgroups with common origins for recent isolates in North America and the UK. Dis Aquat Org, 2007, 76: 193-204

122 Stone DM, Kerr RC, Hughes M, Radford AD, Darby AC. Characterisation of the genomes of four putative vesiculoviruses: tench rhabdovirus, grass carp rhabdovirus, perch rhabdovirus and eel rhabdovirus European X. Arch Virol, 2013, 158: 2371-2377

123 Xiao Y, Shao L, Zhang C, An W. Genomic evidence of homologous recombination in spring viremia of carp virus: a negatively single stranded RNA virus. Virus Res, 2014, 189: 271-279

124 Einer-Jensen K, Harmache A, Biacchesi S, Bremont M, Stegmann A, Lorenzen N. High virulence differences among phylogenetically distinct isolates of the fish rhabdovirus viral hemorrhagic septicaemia virus are not explained by variability of the surface glycoprotein $\mathrm{G}$ or the non-virion protein Nv. J Gen Virol, 2014, 95: 307-316

125 Kell A, Wargo AR, Kurath G. The role of virulence in in vivo superinfection fitness of a vertebrate RNA virus, infections hematopoietic necrosis virus. J Virol, 2013, 87: 8145-8157

126 Hanson L, Dishon A, Kotler M. Herpesviruses that infect fish. Viruses, 2011, 3: 2160-2191
127 van Beurden SJ, Forlenza M, Westphal AH, Wiegertjes GF, Haenen OL, Engelsma MY. The alloherpesviral counterparts of interleukin 10 in European eel and common carp. Fish Shellfish Imm, 2011, 31: 1211-1217

128 Davison AJ, Kurobe T, Gatherer D, Cunningham C, Korf I, Fukuda H, Hedrick RP, Waltzek TB. Comparative genomics of carp herpesviruses. J Virol, 2013, 87: 2908-2922

129 Lovy J, Friend SE. Cyprinid herpesvirus-2 causing mass mortality in goldfish: applying electron microscopy to histological samples for diagnostic virology. Dis Aquat Org, 2014, 108: 1-9

$130 \mathrm{Xu}$ J, Zeng L, Zhang H, Zhou Y, Ma J, Fan YD. Cyprinid herpesvirus 2 infection emerged in cultured gibel carp, Carassius auratus gibelio in China. Vet Microb, 2013, 166: 138-144

131 Costes B, Raj VS, Michel B, Fournier G, Thirion M, Gillet L, Mast J, Lieffrig F, Bremont M, Vanderplasschen A. The major portal of entry of koi herpesvirus in Cyprinus carpio is the skin. J Virol, 2009, 83: 2819-2830

132 Eide KE, Miller-Morgan T, Heidel JR, Kent ML, Bildfella RJ, LaPatra S, Watson G, Jin L. Investigation of koi herpesvirus latency in koi. J Virol, 2011, 85: 4954-4962

133 Reed AN, Izume S, Dolan BP, LaPatra S, Kent M, Dong J, Jin L. Identification of B cells as a major site for cyprinid herpesvirus 3 latency. J Virol, 2014, 88: 9297-309

134 Gotesman M, Kattlun J, Bergmann SM, El-Matbouli M. CyHV-3: the third cyprinid herpesvirus. Dis Aquat Org, 2013, 105: 163-174

135 Dong C, Weng S, Li W, Li X, Yi Y, Liang Q, He J. Characterization of a new cell line from caudal fin of koi, Cyprinus carpio koi, and first isolation of cyprinid herpesvirus 3 in China. Virus Res, 2011, 161: $140-149$

136 Aoki T, Hirono I, Kurokawa K, Fukuda H, Nahary R, Eldar A, Davison AJ, Waltzek TB, Bercovier H, Hedrick RP. Genome sequencing of three koi herpesvirus isolates representing the expanding distribution of an emerging disease threatening koi and common carp worldwide. J Virol, 2007, 81: 5058-506

137 Kim HJ, Kwon SR. Evidence for two koi herpesvirus (KHV) genotypes in South Korea. Dis Aquat Org, 2013, 104: 197-202

138 Davison AJ, Kurobe T, Gatherer D, Cunningham C, Korf I, Fukuda H, Hedrick RP, Waltzek TB. Comparative genomics of carp herpesviruses. J Virol, 2013, 87:2908-2922

139 Davison AJ. Channel catfish virus: a new type of herpesvirus. Virology, 1992, 186: 9-14

140 van Beurden SJ, Bossers A, Voorbergen-Laarman MH, Haenen OL, Peters S, Abma-Henkens MH, Peeters BP, Rottier PJ, Engelsma MY. Complete genome sequence and taxonomic position of anguillid herpesvirus 1. J Gen Virol, 2010, 91(Pt 4): 880-887

141 van Beurden SJ, Gatherer D, Kerr K, Galbraith J, Herzyk P, Peeters BP, Rottier PJ, Engelsma MY, Davison AJ. Anguillid herpesvirus 1 transcriptome. J Virol, 2012, 86: 10150-10161

142 van Beurden SJ, Peeters BP, Rottier PJ, Davison AJ, Engelsma MY. Genome-wide gene expression analysis of anguillid herpesvirus-1. BMC Genomics, 2013, 14: 83

143 Ackermann M, Koriabine M, Hartmann-Fritsch F, de Jong PJ, Lewis TD, Schetle N, Work TM, Dagenais J, Balazs GH, Leong JA. The genome of chelonid herpesvirus 5 harbors atypical genes. PLoS One, 2012, 7: e46623

144 Ren W, Chen H, Renault T, Cai Y, Bai C, Wang C, Huang J. Complete genome sequence of acute viral necrosis virus associated with massive mortality outbreaks in the Chinese scallop, Chlamys farreri. Virol J, 2013, 10:1-10

145 Ito T, Maeno Y. Susceptibility of Japanese Cyprininae fish species to cyprinid herpesvirus 2. Vet Microb, 2014, 169: 128-134

146 Marcos-Lopez M, Waltzek TB, Hedrick RP, Baxa DV, Garber AF, Liston R, Johnsen E, Backman S, Ferguson HW. Characterization of a novel alloherpesvirus from Atlantic cod (Gadus morhua). J Vet Diagn Invest, 2012, 24: 65-73

147 Zhang H, Zeng L, Fan Y, Zhou Y, Xu J, Ma J. A Loop-mediated isothermal amplification assay for rapid detection of cyprinid herpesvirus 2 in gibel carp (Carassius auratus gibelio). Sci World J, 2014, 2014: 716413 
148 Xu L, Podok P, Xie J, Lu L. Comparative analysis of differential gene expression in kidney tissues of moribund and surviving crucian carp (Carassius auratus gibelio) in response to cyprinid herpesvirus 2 infection. Arch Virol, 2014, 159: 1961-1974

149 Sunarto A, McColl KA, Crane MS, Schat KA, Slobedman B, Barnes AC, Walker PJ. Characteristics of cyprinid herpesvirus 3 in different phases of infection: implications for disease transmission and control. Virus Res, 2014, 188: 45-53

150 Yi Y, Zhang H, Lee X, Weng S, He J, Dong C. Extracellular virion proteins of two Chinese CyHV-3/KHV isolates, and identification of two novel envelope proteins. Virus Res, 2014, 191C: 108-116

151 Sunyer JO. Fishing for mammalian paradigms in the teleost immune system. Nat Imm, 2013, 14: 320-326

152 Sun JC, Ugolini S, Vivier E. Immunological memory within the innate immune system. EMBO J, 2014, 33: 1295-1303

153 Adamek M, Steinhagen D, Irnazarow I, Hikima JI, Jung TS, Aoki T. Biology and host response to Cyprinid herpesvirus 3 infection in common carp. Dev Comp Immunol, 2014, 43: 151-159

154 Munang'andu HM, Mutoloki S, Evensen $\varnothing$. Acquired immunity and vaccination against infectious pancreatic necrosis virus of salmon. Dev Comp Immunol, 2014, 43: 184-196

155 Somamoto T, Koppang EO, Fischer U. Antiviral functions of CD8 ${ }^{+}$cytotoxic T cells in teleost fish. Dev Comp Immunol, 2014, 43: 197-204

156 Zhang YB, Gui JF. Molecular regulation of interferon antiviral response in fish. Dev Comp Immunol, 2012, 38: 193-202

157 Wang L, Qiu L, Zhou Z, Song L. Research progress on the mollusc immunity in China. Dev Comp Immunol, 2013, 39: 2-10

$158 \mathrm{Li} \mathrm{F}$, Xiang J. Recent advances in researches on the innate immunity of shrimp in China. Dev Comp Immunol, 2013, 39: 11-26

159 Wang XW, Wang JX. Diversity and multiple functions of lectins in shrimp immunity. Dev Comp Immunol, 2013, 39: 27-38

160 Zhu LY, Nie L, Zhu G, Xiang LX, Shao JZ. Advances in research of fish immune-relevant genes: a comparative overview of innate and adaptive immunity in teleosts. Dev Comp Immunol, 2013, 39: 39-62

161 Peng XX. Proteomics and its applications to aquaculture in China: infection, immunity, and interaction of aquaculture hosts with pathogens. Dev Comp Immunol, 2013, 39: 63-71

162 Zhang S, Wang Z, Wang H. Maternal immunity in fish. Dev Comp Immunol, 2013, 39: 72-78

163 Esteban MÁ. An overview of the immunological defenses in fish skin. ISRN Imm, 2012, Article ID 853470, 1-29

$164 \mathrm{Xu} \mathrm{Z}$, Parra D, Gómez D, Salinas I, Zhang YA, von Gersdorff Jørgensen L, Heinecke RD, Buchmann K, LaPatra S, Sunyer JO. Teleost skin, an ancient mucosal surface that elicits gut-like immune responses. Proc Natl Acad Sci USA, 2013, 110: 13097-13102
165 Bordon Y. Evolution: a gutsy defence of the skin. Nat Rev Immunol, 2013, 13: 616-617

166 Pasparakis M, Haase I, Nestle FO. Mechanisms regulating skin immunity and inflammation. Nat Rev Immunol, 2014, 14: 289-301

167 Collet B. Innate immune responses of salmonid fish to viral infections. Dev Comp Immunol, 2014, 43: 160-173

168 Castro R, Jouneau L, Pham HP, Bouchez O, Giudicelli V, Lefranc MP, Quillet E, Benmansour A, Cazals F, Six A, Fillatreau S, Sunyer $\mathrm{O}$, Boudinot P. Teleost fish mount complex clonal IgM and IgT responses in spleen upon systemic viral infection. PLoS Pathog, 2013, 9: 1003098

169 Wang T, Secombes CJ. The cytokine networks of adaptive immunity in fish. Fish Shellfish Immunol, 2013, 35: 1703-1718

170 Rombout JH, Yang G, Kiron V. Adaptive immune responses at mucosal surfaces of teleost fish. Fish Shellfish Immunol, 2014, pii: S1050-4648(14)00305-2

171 Ye J, Kaattari IM, Ma C, Kaattari S. The teleost humoral immune response. Fish Shellfish Immunol, 2013, 35: 1719-1728

172 Grayfer L, Andino Fde J, Chen G, Chinchar GV, Robert J. Immune evasion strategies of ranaviruses and innate immune responses to these emerging pathogens. Viruses, 2012, 4: 1075-1092

173 Chen ZY, Lei XY, Zhang QY. The antiviral defense mechanisms in mandarin fish induced by DNA vaccine against a rhabdovirus. Vet Microbiol, 2012, 157: 264-275

174 Shi Y, Zhao Z, Zhu XP, Chen KC, Zhang QY. Expression and functional characterization of a gene associated with retinoid-interferon-induced mortality 19 (GRIM-19) from orange-spotted grouper (Epinephelus coioides). Fish Shellfish Imm, 2013, 34: 273-279

175 Zhu R, Wang J, Lei XY, Gui JF, Zhang QY. Evidence for Paralichthys olivaceus IFITM1 antiviral effect by impeding viral entry into target cells. Fish Shellfish Immunol, 2013, 35: 918-926

176 Zhu R, Chen ZY, Wang J, Yuan JD, Liao XY, Gui JF, Zhang QY. Thymus cDNA library survey uncovers novel features of immune molecules in Chinese giant salamander (Andrias davidianus). Dev Comp Immunol, 2014, 46: 413-422

177 Sun F, Zhang YB, Liu TK, Gan L, Yu FF, Liu Y, Gui JF. Characterization of fish IRF3 as an IFN-inducible protein reveals evolving regulation of IFN response in vertebrates. J Immunol, 2010, 185: 7573-7582

178 Sun F, Zhang YB, Liu TK, Shi J, Wang B, Gui JF. Fish MITA activation serves as a mediator for distinct fish IFN gene activation dependent on IRF3 or IRF7. J Immunol, 2011, 187: 2531-2539

179 Liu TK, Zhang YB, Liu Y, Sun F, Gui JF. Cooperative roles of fish PKZ and PKR in IFN-mediated antiviral response. J Virol, 2011, 85: $12769-12780$

Open Access This article is distributed under the terms of the Creative Commons Attribution License which permits any use, distribution, and reproduction in any medium, provided the original author(s) and source are credited. 